\title{
Year to year and seasonal variations in vector bionomics and malaria transmission in a humid savannah village in west Burkina Faso
}

\author{
Author(s): K. R. Dabiré, A. Diabaté , L. Paré-Toé , J. Rouamba , A. Ouari , D. Fontenille, and T. Baldet
} Source: Journal of Vector Ecology, 33(1):70-75. 2008.

Published By: Society for Vector Ecology

DOI: http://dx.doi.org/10.3376/1081-1710(2008)33[70:YTYASV]2.0.CO;2

URL: http://www.bioone.org/doi/full/10.3376/1081-1710\%282008\%2933\%5B70\%3AYTYASV

$\% 5 \mathrm{D} 2.0 . \mathrm{CO} \% 3 \mathrm{~B} 2$

BioOne (www.bioone.org) is a nonprofit, online aggregation of core research in the biological, ecological, and environmental sciences. BioOne provides a sustainable online platform for over 170 journals and books published by nonprofit societies, associations, museums, institutions, and presses.

Your use of this PDF, the BioOne Web site, and all posted and associated content indicates your acceptance of BioOne's Terms of Use, available at www.bioone.org/page/terms_of_use.

Usage of BioOne content is strictly limited to personal, educational, and non-commercial use. Commercial inquiries or rights and permissions requests should be directed to the individual publisher as copyright holder. 


\title{
Year to year and seasonal variations in vector bionomics and malaria transmission in a humid savannah village in west Burkina Faso
}

\author{
K.R. Dabiré ${ }^{\bowtie}$, A. Diabaté1, ${ }^{2}$, L. Paré-Toé1 ${ }^{1}$ J. Rouamba ${ }^{1}$, A. Ouari ${ }^{1}$, D. Fontenille ${ }^{3}$, and T. Baldet ${ }^{4}$ \\ ${ }^{1}$ Institut de Recherche en Sciences de la Santé (IRSS) /Centre Muraz, BP 390, Bobo-Dioulasso, Burkina Faso \\ ${ }^{2}$ Laboratory of Malaria and Vector Research /NIAID/ NIH, Rockville, Washington, D.C., U.S.A. \\ ${ }^{3}$ Laboratoire de Lutte contre les Insectes Nuisibles (LIN)-IRD, 911 Agropolis, BP 5045, \\ 34032 Montpellier Cedex 1, France \\ ${ }^{4}$ Cirad UPR16, Campus international de Baillarguet, Montpellier, France
}

Received 21 April 2007; Accepted 17 December 2007

\begin{abstract}
A longitudinal entomological study was carried out from 1999 to 2001 in Lena, a humid savannah village in the western region of Burkina Faso in order to establish malaria vector bionomics and the dynamics of malaria transmission. In the first year, malaria transmission was mainly due to An. gambiae s.s., but during the two later years was due to An. funestus, which were observed in high frequency towards the end of the rainy season. PCR identification of samples of An. gambiae s.l. showed $93 \%$ to be An. gambiae s.s. and $7 \%$ An. arabiensis. An. funestus constituting more than $60 \%$ of the vectors were identified in PCR as An. funestus s.s. The persistence of intense vectorial activity in this village was probably due to the road building in a swampy area creating a semi-permanent swamp that provided large sites for larval mosquitoes. These swampy sites seemed to be more favorable for An. funestus than for An. gambiae s.s. Thus, land development must be monitored and subjected to planning to minimize vector proliferation. Such a system of planning could lead to the restriction or even elimination of the swamp that is the source of larvae developing in the heart of the village. Journal of Vector Ecology 33 (1): 70-75. 2008.
\end{abstract}

Keyword Index: Anopheles funestus, Anopheles gambiae s.s., malaria transmission, semi-permanent swamp, Burkina Faso.

\section{INTRODUCTION}

Cotton is the main crop in the western region of Burkina Faso. To facilitate the management of this crop, the government and local community, in collaboration with the national cotton management company, have renovated or built road and storage facilities. This caused local changes in the ecological conditions that favored species formerly only considered as secondary vectors of malaria. In such a context, it is crucial to characterize the bio-ecology of such vectors and to evaluate their role in malaria transmission. Based on recent PCR techniques enabling us to address the species and molecular identification of the Anopheles gambiae and Anopheles funestus complexes (Scott et al. 1993, Favia et al. 2001, Koekemoer et al. 2002), the aim of the present study was to investigate the bionomics of malaria vectors and their role in malaria transmission in an environmentally-modified village in western Burkina Faso formerly dominated by An. gambiae s.l. (Robert et al. 1985).

\section{MATERIALS AND METHODS}

\section{Study site}

Anopheles mosquitoes were collected in Lena $\left(11^{\circ} 18^{\prime} \mathrm{N}\right.$; $03^{\circ} 53^{\prime} \mathrm{W}$ ), a humid savannah village in southwestern Burkina Faso from 1999 to 2001. In this region, there are two distinct seasons: rains occur only from May to October, with a long dry season from November to April. The average annual rainfall ranged from 1,000 to $1,200 \mathrm{~mm}$ in the last five years. The larval habitats consist mostly of rain-filled puddles and a semi-permanent swamp on either side of a small roadway suitable for An. funestus development. This roadway was built at the end of 1998 to facilitate crossing the swamp that formerly flooded the road.

\section{Mosquito collections}

Anopheles mosquitoes were sampled from February 1999 to December 2001 during the rainy season, four times per month by human landing catches and indoor insecticide aerosol spray catches. The human landing catches were carried out by informed volunteers who were provided with free and rapid treatment when they showed fever and Plasmodium falciparum parasitemia according to a WHO-recommended regimen. To evaluate human biting rates, pairs of humans sat indoors and outdoors collecting mosquitoes landing on themselves by using flashlights and glass tubes. Collections were carried out between 18:00 and 06:00 $\mathrm{h}$ inside and just outside eight houses in various parts of the swamp. To compensate for variation in catching efficiency, collectors rotated between houses on successive nights.

Indoor-resting females were caught by spraying village huts with pyrethroids. Female mosquitoes were knocked 
down and immediately retrieved from white sheets laid on the floor of sprayed huts. Mosquitoes were dissected and the head and thorax preserved to determine their infection status. Legs were removed and kept dry for molecular species identification. Blood-fed females were stored in 1.5 $\mathrm{ml}$ tubes. Muirhead-Thomson (1958) pit traps were used to catch samples of exophilic mosquitoes in 2000.

\section{Laboratory processing of mosquitoes}

Anophelines were morphologically identified using keys of Gillies and Coetzee (1987). Later, some of the females were tested by ELISA for P. falciparum CSP (Wirtz et al. 1987) and those positive were processed by PCR for molecular identification of the An. gambiae complex species and An. funestus group and An. gambiae molecular forms (Scott et al. 1993, Favia et al. 2001, Cohuet et al. 2003). Blood meals were identified as human, bovine, sheep/goat, pig, or donkey using the ELISA technique of Beier et al. (1988).

\section{Data analysis}

The human biting rate (HBR) was calculated as the number mosquitoes captured per person per night. The rate of endophagy was defined as the proportion of the mosquitoes that were caught indoors with landing collections. The sporozoite rate was defined as the proportion of mosquitoes found positive for P. falciparum CS protein. The anthropophilic rate was calculated as the proportion of human blood among all blood meals tested. The entomological inoculation (EIR) was calculated as the product of HBR and the sporozoite rate of mosquitoes caught on landing collections.

\section{RESULTS}

\section{Species composition and endophagic rate}

In the three years, 1,647 An. gambiae s.l., 2,161 An. funestus, and $111 \mathrm{An}$. nili were identified. An. funestus predominated among malaria vectors with some seasonal and annual variations. An. funestus represented $60 \%$, vs $38 \%$ for An. gambiae s.l. and 2\% An. nili. However, in 1999, An. gambiae s.l. was the main malaria vector with $65 \%$ of the total vectors vs $34 \%$ of An. funestus and only $1 \%$ for $A n$. nili. During the two later years, the vector population was dominated by An. funestus with $74 \%$ and $72 \%$ in 2000 and 2001, respectively, with a small increase of An. nili from 2 to $3 \%$ (Figure 2).

As shown in Table 1, indoor and outdoor catches of An. gambiae s.l. did not differ significantly from equality with each other within the same year $\left(\chi^{2}=3, \mathrm{df}=2, \mathrm{P}=0.2\right)$. In contrast, $A n$. funestus was significantly more endophagic than exophagic in each year and its endophagic rate increased greatly from 1999 to $2001\left(\chi^{2}=19.4, \mathrm{df}=1, \mathrm{P}<0.001\right)$. An. nili tended to exophagy but outdoor catches did not significantly exceed indoor ones in any of the year.

\section{Indoor resting collection and endophilic rate}

From July 2000 to December 2001, 1,005 mosquitoes were collected in indoor spray collection of which 187 were An. gambiae s.l., 627 An. funestus, and 1 An. nili as malaria vectors. During 2000, only 14 An. gambiae s.l. and 33 An. funestus were caught in Muirhead-Thomson traps. Based on these data, it was concluded that An. gambiae s.l. and An. funestus were endophilic.

\section{Monthly variation of human biting rate}

In 1999, biting of An. gambiae s.l. began at a low level in July reaching a peak of $25 / \mathrm{b} / \mathrm{h} / \mathrm{n}$ in September and

Table 1. Endophagic rate of vectors caught in Lena village from 1999-2001.

\begin{tabular}{|c|c|c|c|c|c|}
\hline \multirow{2}{*}{ Years } & \multirow{2}{*}{ Mosquito species } & \multicolumn{2}{|c|}{ Indoors } & \multicolumn{2}{|c|}{ Outdoors } \\
\hline & & $\mathrm{N}$ & $\%$ & $\mathrm{~N}$ & $\%$ \\
\hline \multirow{3}{*}{1999} & An. gambiae s.l. & 459 & 48.4 & 489 & 51.6 \\
\hline & An. funestus & 243 & $54.2^{*}$ & 205 & 45.8 \\
\hline & An. nili & 9 & 36 & 16 & 64 \\
\hline \multirow{3}{*}{2000} & An. gambiae s.l. & 184 & 52.3 & 168 & 47.7 \\
\hline & An. funestus & 555 & $57.6^{\star *}$ & 409 & 42.4 \\
\hline & An. nili & 16 & 48.5 & 17 & 51.4 \\
\hline \multirow{3}{*}{2001} & An. gambiae s.l. & 178 & 53.6 & 154 & 46.4 \\
\hline & An. funestus & 500 & $67.8^{* *}$ & 237 & 32.2 \\
\hline & An. nili & 19 & 36.5 & 33 & 63.5 \\
\hline
\end{tabular}

\footnotetext{
${ }^{\star} P<0.05$.

${ }^{\star *} P<0.001\left(\chi^{2}=19.4, \mathrm{df}=1, P<0.001\right)$.
} 
Figure 1. Relative frequencies of vector species caught in indoor human landing from 1999-2001.

An. gambiae s.s.

1999

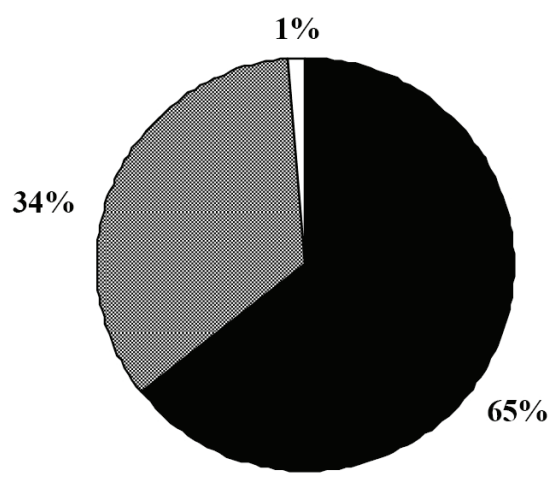

$\mathrm{n}=711$
0 An. funestus

2000

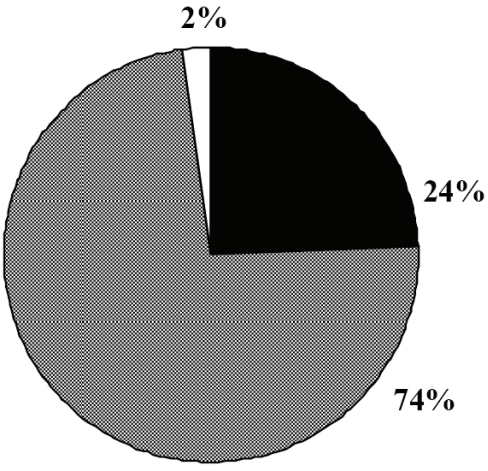

$\mathrm{n}=\mathbf{7 5 5}$
An. nili

2001

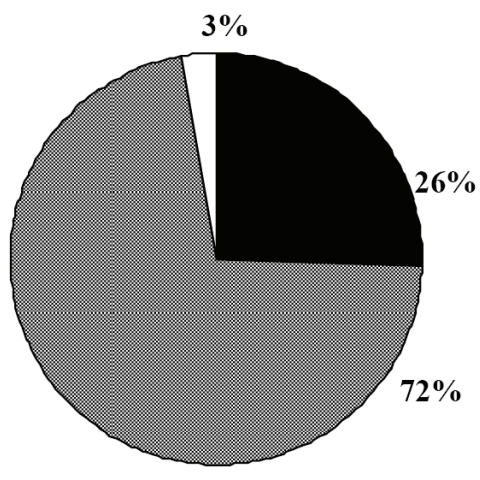

$\mathrm{n}=697$

Table 2. Variation among years in entomological inoculation rate (EIR) in Lena village from 1999-2001.

\begin{tabular}{|c|c|c|c|c|c|c|c|}
\hline & \multirow[b]{2}{*}{ Years } & \multicolumn{3}{|c|}{ Anopheles gambiae s.s. } & \multicolumn{3}{|c|}{ Anopheles funestus } \\
\hline & & Parity rate & $\begin{array}{c}\text { Sporozoite } \\
\text { rate }\end{array}$ & EIR & Parity rate & $\begin{array}{l}\text { Sporozoite } \\
\text { rate }\end{array}$ & EIR \\
\hline \multirow[b]{2}{*}{1999} & Indoor & $\begin{array}{c}59.1 \\
(77 / 129)\end{array}$ & $\begin{array}{c}6.8 \\
(25 / 366)\end{array}$ & 119 & $\begin{array}{c}73.3 \\
(11 / 15)\end{array}$ & $\begin{array}{c}16.1 \\
(5 / 31)\end{array}$ & 73 \\
\hline & Outdoor & $\begin{array}{c}62.1 \\
(77 / 124)\end{array}$ & $\begin{array}{c}5.7 \\
(19 / 333)\end{array}$ & 112 & $\begin{array}{c}50 \\
(1 / 2)\end{array}$ & $\begin{array}{c}7.1 \\
(1 / 14)\end{array}$ & 5 \\
\hline \multirow[b]{2}{*}{2000} & Indoor & $\begin{array}{c}74.6 \\
(50 / 67)\end{array}$ & $\begin{array}{c}12 \\
(22 / 184)\end{array}$ & 85 & $\begin{array}{c}62.1 \\
(64 / 103)\end{array}$ & $\begin{array}{c}4.8 \\
(11 / 230)\end{array}$ & 86 \\
\hline & Outdoor & $\begin{array}{c}71 \\
(44 / 62)\end{array}$ & $\begin{array}{c}10.9 \\
(19 / 175)\end{array}$ & 70 & $\begin{array}{c}59.9 \\
(53 / 89)\end{array}$ & $\begin{array}{c}3.0 \\
(7 / 230)\end{array}$ & 53 \\
\hline \multirow[b]{2}{*}{2001} & Indoor & $\begin{array}{c}82.8 \\
(48 / 58)\end{array}$ & $\begin{array}{c}9.8 \\
(18 / 183)\end{array}$ & 68 & $\begin{array}{c}83.5 \\
(86 / 103)\end{array}$ & $\begin{array}{c}6.5 \\
(24 / 370)\end{array}$ & 123 \\
\hline & Outdoor & $\begin{array}{c}74.5 \\
(48 / 58)\end{array}$ & $\begin{array}{c}7.9 \\
\left(12 / 151^{\circ}\right.\end{array}$ & 47 & $\begin{array}{c}77.1 \\
(37 / 48)\end{array}$ & $\begin{array}{c}5.9 \\
(13 / 222)\end{array}$ & 51 \\
\hline
\end{tabular}

Table 3. Origin of blood meals of vectors caught in Lena (percentages are between brackets).

\begin{tabular}{cccc}
\hline Mosquito species & Human & $\begin{array}{c}\text { Others (bovine, ovine, or } \\
\text { pig) }\end{array}$ & $\begin{array}{c}\text { Mixed (human and } \\
\text { others) }\end{array}$ \\
\hline An. gambiae s.s. & $51(62)$ & $10(13.4)$ & $20(24.6)$ \\
An. funestus s.s. & $17(56.6)$ & $11(36.7)$ & $2(6.6)$ \\
\hline
\end{tabular}




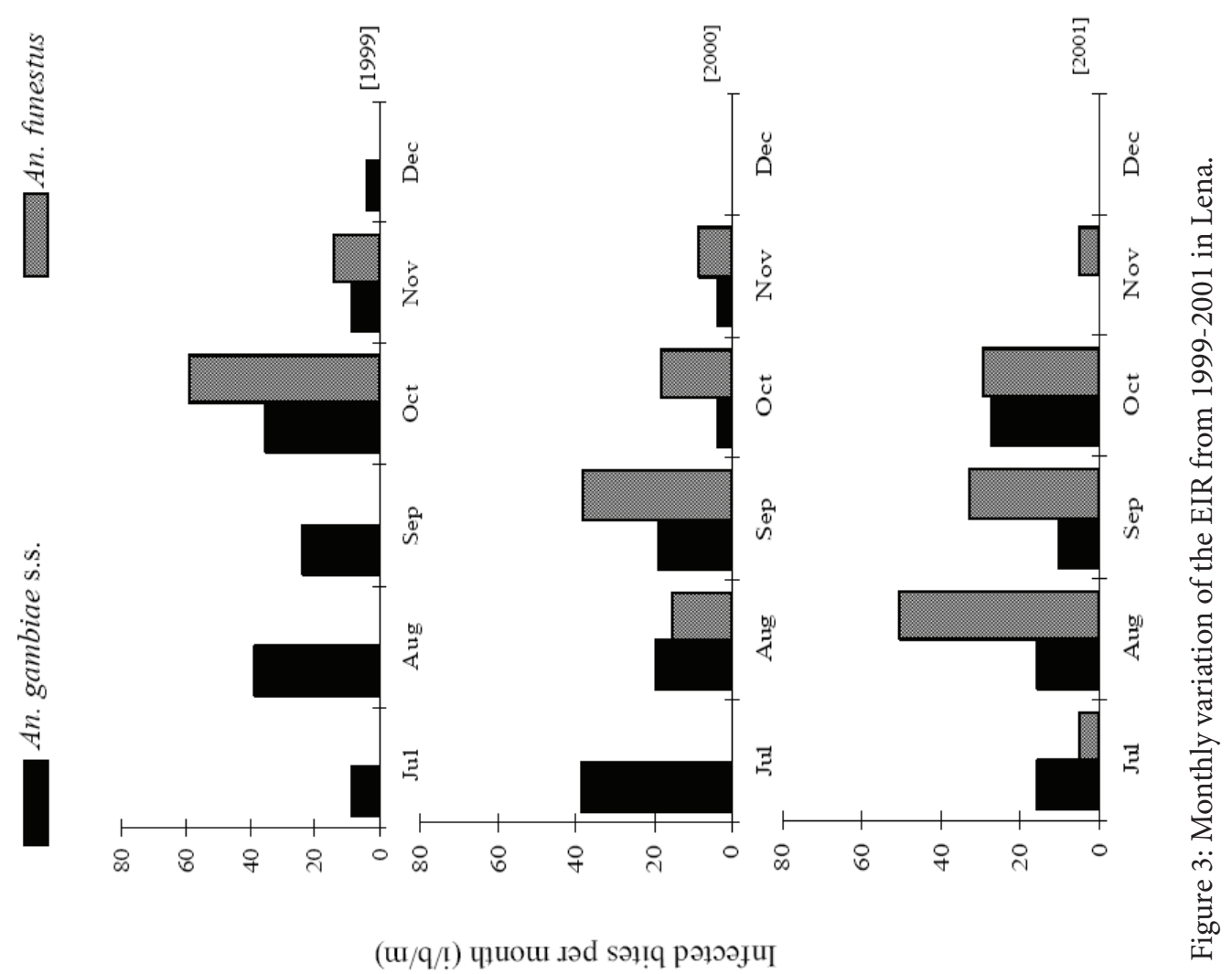

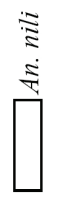
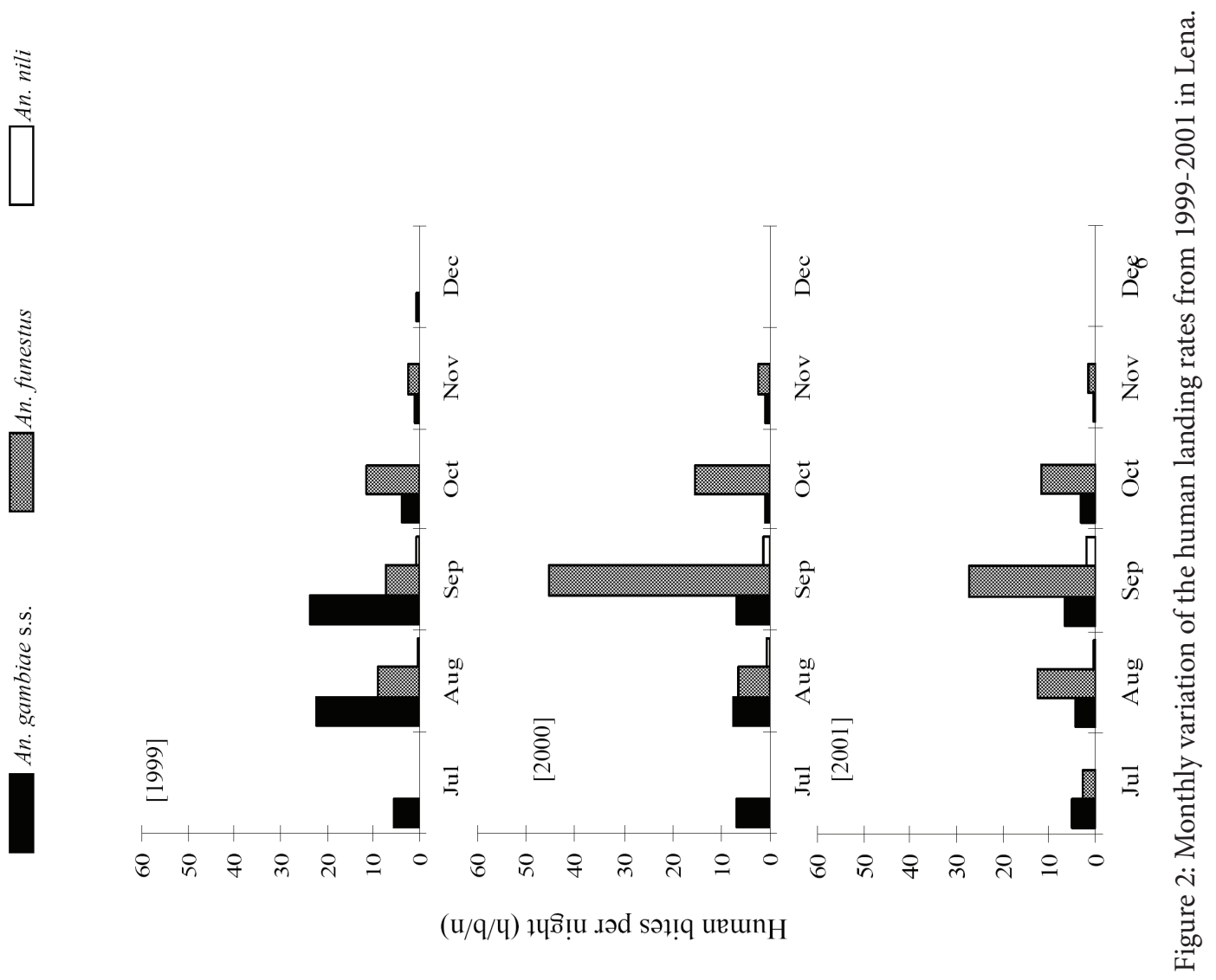
decreased sharply in October. An. funestus remained below $15 / \mathrm{b} / \mathrm{h} / \mathrm{n}$ in all months (Figure 3 ). These two vectors were found biting until December at low frequencies. In 2000, An. gambiae s.l. biting predominated until August after which An. funestus increased and reached a peak of $45 \mathrm{~b} / \mathrm{h} /$ $\mathrm{n}$ in September. Thereafter, the An. gambiae s.l. biting rate declined and neither An. funestus nor An. gambiae s.l. were observed in December. In 2001, An. funestus predominated as early as August and remained predominant until the end of the rainy season. Overall, the relative proportion of $A n$. gambiae s.l. decreased and An. funestus increased.

\section{Parity, circumsporozoite, and entomological inoculation rates}

Data on parity and sporozoite rates of each species in each year are shown in Table 2. Because there were no major changes in parity rate, variation in EIR (Figure 4) resembled those in sporozoite rates, i.e., predominance of An. gambiae until September in 1999 with An. funestus thereafter. In 2000 and 2001, An. funestus predominated even in the earlier months (Table 2). P. falciparum CS protein was analyzed in 330 females of An. gambiae s.l. for species and molecular form identification. Only $7 \%(\mathrm{n}=23)$ were identified as An. arabiensis vs $93 \%(\mathrm{n}=307)$ as An. gambiae s.s. No $A n$. arabiensis were found to be infected with $P$. falciparum. Among 210 females identified as An. gambiae s.s., $28 \%$ $(\mathrm{n}=60)$ were characterized as the M molecular form vs $72 \%$ of the $S(n=150)$ molecular form. Three hundred female An. funestus (100 in each year) were analysed by PCR and identified as An. funestus s.s.

\section{The anthropophilic rate}

Eighty-two An. gambiae s.s. and 30 An. funestus randomly sampled from indoor resting females were tested for their origin of blood meal. These two species had anthrophilic rates reaching up to $55 \%$, with a few cases of mixed meals (Table 3).

\section{DISCUSSION}

Because Lena is a typical savannah village, mosquito larval habitats are mainly rain-dependent and vector activities coincide with the rainy season. Thus, vector populations were dominated by An. gambiae s.l. during most of the rainy season. However, we observed some residual and intense vector activity occurring toward the end of the rainy season resulting from the appearance of An. funestus concomitantly with An. gambiae s.l., two major anthrophilic vectors. The first dominated the vector distribution especially in the years 2000 and 2001. Indeed the occurrence of An. funestus did not appear to modify overall vector abundance, but the proportion of each species. That led to a specific vector dynamic and malaria transmission pattern resulting in a high inoculation rate toward the end of the rainy season where the natural larval sites were drying. This increase of An. funestus apparently resulted from a semi-permanent swamp that favored $A n$. gambiae s.l. at the beginning of the rainy season before the vegetation grew abundantly and covered the water surface. As An. gambiae developed better in sites exposed to the sun and without vegetation (Carnevale et al. 1999), they had less ability to colonize this kind of breeding site and An. funestus had the opposite requirements. Indeed, there was more rain in 2000 than the other two years which might lead one to expect more vectors there, but this was not the case. In each year, August had the most rainfall but there was not a corresponding peak of the two vectors. The presence of a swamp is apparently the main cause of increased vector abundance toward the end of the rainy season. The dumping in the swamp of waste soil for road construction made the site more favorable to An. funestus. Furthermore, the volume of rain that fell between June and August was relatively higher and might contribute first, to leach away the breeding sites colonized by An. gambiae and second, to fill the swamps favorable to An. funestus.

In conclusion, the modification of the natural landscape by human activities can greatly change vector composition, shifting the malaria transmission pattern as suggested by our study. This landscape modification must be monitored and controlled by a system of planning permission to prevent vector proliferation that could interfere with local efforts to reduce the malaria burden. This consent action could lead to the restriction or even the elimination of the swamp which now allows vector breeding in the heart of the village.

\section{Acknowledgments}

This study was supported by a grant from Danida, French Ministry of Cooperation and by the Programme Pal+ of the French Ministry of Scientific Research. We are grateful to the volunteers of Lena who made this study possible. We thank also Dr. Ole Skovmand for his helpful suggestions and comments during the drafting of this manuscript.

\section{REFERENCES CITED}

Antonio-Nkondjio, C., P. Awono-Ambene, J. C. Toto, J.Y. Meunier, S. Zabaze-Kemleu, R. Nyambam, C.S. Wondji, T. Tchuimkam, and D. Fontenille. 2002. High malaria transmission intensity in a village close to Yaounde, the capital city of Cameroon. J. Med. Entomol. 39: 350355.

Antonio-Nkondjio, C., F. Simard, P. Awono-Ambene, P. Ngassam, J.C. Toto, T. Tchuinkam, and D. Fontenille. 2005. Malaria vectors and urbanisation in the equatorial forest region of south Cameroon. Trans. R. Soc. Trop. Med. Hyg. 99: 347-354.

Awono-Ambene, H.P., P. Kengne, F. Simard, C. AntonioNkondjio, and D. Fontenille. 2004. Description and bionomics of Anopheles (Cellia) ovengensis (Diptera: Culicidae) a new malaria vector species of the Anopheles nili group from south Cameroon. J. Med. Entomol. 41: 561-568. 
Beier, J.C., P.V. Perking, R.A. Wirtz, J. Koros, D. Diggs, T.P.I.I. Gargan, and D.K. Koetch. 1988. Blood meal identification by direct enzyme-linked immunosorbent assay (Elisa) tested on Anopheles (Diptera: Culicidae) in Kenya. J. Med. Entomol. 25: 9-16.

Carnevale, P., P. Guillet, V. Robert, D. Fontenille, J. Doannio, M. Coosemans, and J. Mouchet. 1999. Diversity of malaria vectors in rice growing areas of the Afrotropical region. Parassitologia 41: 273-276.

Cohuet, A., F. Simard, J.C. Toto, P. Kengne, M. Coetzee, and D. Fontenille. 2003. Species identification within the Anopheles funestus group of malaria vectors in Cameroon and evidence for a new species. Am. J. Trop. Hyg. 69: 200-205.

Coetzee, M., M. Craig, and D. Le Sueur. 2000. Distribution of African malaria mosquiotes belonging to the Anopheles gambiae complex. Parasitol. Today 16: 74-77.

Dabiré, K.R., T. Baldet, A. Diabaté, I. Dia, A. Cohuet., C. Costantini, T.R. Guiguemdé, and D. Fontenille. 2007. Anopheles funsestus s.l. Giles (Diptera: Culicidae) in a humid savannah area of western Burkina Faso: bionomics, insecticide resistance status and role in malaria transmission. J. Med. Entomol. (in press).

Diabaté A., T. Baldet, F. Chandre, M. Akogbeto, F. Darriet, C. Brengues, T.R. Guiguemdé, P. Guillet, J. Hemingway, and J.M. Hougard. 2002. The role of agricultural use of insecticides in resistance to pyrethroids in Anopheles gambiae s.l. in Burkina Faso. Am. J. Trop. Hyg. 67: 617622.

Favia, G., A. Lanfrancotti, L. Spanos, I. Sideén-Kiamos, and C. Louis. 2001. Molecular characterisation of ribosomal DNA polymorphisms discriminating among chromosomal forms of Anopheles gambiae s.s. Insect Mol. Biol. 10: 19-23.

Gillies, M.T. and M. Coetzee. 1987. A supplement to the Anophelinae of Africa South of the Sahara (Afrotropical Region), vol. 55. Publications of the South African
Institute of Medical Research, Johannesburg, South Africa, 143pp.

Koekemoer, L.L., M.M. Weeto, L. Kamau, R.H. Hunt, and M. Coetzee. 2002. A cocktail polymerase chain reaction (PCR) assay to identify members of the Anopheles funestus (Diptera : Culicidae) group. Am. J. Trop. Med. Hyg. 66: 804-811.

Mouchet, J., P. Carnevale, M. Coosemans, J. Julvez, S. Manguin, D. Richard-Lenoble, and J. Sircoulon. 2004. Biodiversité du paludisme dans le monde. John Libbey Eutotext, $428 \mathrm{pp}$.

Muirhead-Thomson RC. 1958. A pit shelter for sampling outdoor mosquito populations. Bull. Wld. Hlth. Org. 19: 1116-1118.

Robert, V., P. Carnevale, V. Ouedraogo, V. Petrarca, and M. Coluzzi. 1985. La transmission du paludisme humain dans un village de savane du Sud-Ouest du Burkina Faso. Ann. Soc. Belge Med. Trop. 68: 107-121.

Scott, J.A., W.G. Brogdon, and F.M. Collins. 1993. Identification of single specimens of Anopheles gambiae complex by the polymerase chain reaction. Am J. Trop. Med. Hyg. 49: 520-529.

Touré Y.T., V. Petrarca, S.F. Traoré, A. Coulibaly, H.M. Maiga, O. Sangaré, M. Sow, M.A. Di Decco, and M. Coluzzi. 1998. The distribution and inversion polymorphism of chromosomally recognised taxa of the Anopheles gambiae complex in Mali, West Africa. Parassitologia 40: 477-511.

Tripet, F., T. Thiemann, and G. C. Lanzaro. 2005. Effect of seminal fluids in mating between $\mathrm{M}$ and $\mathrm{S}$ forms of Anopheles gambiae. J. Med. Entomol. 42: 596-603.

Wirtz, R.A., F. Zavala, Y. Charoenvit, G.H. Campbell, T.R. Burkot, I. Schneider, K.M. Esser, R.L. Beaudoin, and G. Andre. 1987. Comparative testing of monoclonal antibodies against Plasmodium falciparum sporozoïtes for Elisa development. Bull. Wld. Hth. Org. 65: 39-45. 